\title{
Effects of Selected Opioid Agonists and Antagonists on DMT- and LSD-25-Induced Disruption of Food-Rewarded Bar Pressing Behavior in the Rat
}

\author{
Diane M. Ruffing ${ }^{1}$ and Edward F. Domino ${ }^{1,2}$ \\ ${ }^{1}$ Division of Pharmacology, Lafayette Clinic, 951 East Lafayette, Detroit, Michigan 48207, USA \\ 2 The University of Michigan, Ann Arbor, Michigan 48109, USA
}

\begin{abstract}
Several opioid agonists and antagonists interact with N,N-dimethyltryptamine (DMT) and lysergic acid diethylamide-25 (LSD) in adult male Holtzman rats trained on a positive reinforcement, fixed ratio $4\left(\mathrm{FR}_{4}\right)$ behavioral schedule, i.e., a reward of $0.01 \mathrm{ml}$ sugar-sweetened milk was earned on every fourth bar press. DMT $(3.2$ and $10.0 \mathrm{mg} / \mathrm{kg})$ and LSD $(0.1 \mathrm{mg} / \mathrm{kg})$ given IP with $0.9 \% \mathrm{NaCl}$ pretreatment, disrupted food-rewarded FR4 bar pressing. Animals were pretreated IP $(10-15 \mathrm{~min})$ with predetermined, behaviorally noneffective doses of morphine, methadone, naltrexone, and the $(+)$ - and (-)-enantiomers of naloxone prion to receiving DMT or LSD. Dose-dependent effects were shown with opioid agonist pretreatment. Morphine $(0.32-1.0 \mathrm{mg} / \mathrm{kg})$ and methadone $(0.32 \mathrm{mg} / \mathrm{kg})$ significantly antagonized the bar pressing disruption induced by DMT and LSD. Larger doses of morphine $(3.2 \mathrm{mg} / \mathrm{kg})$ and methadone $(1.0-$ $3.2 \mathrm{mg} / \mathrm{kg}$ ) potentiated only LSD-induced effects, with no effect on DMT-treated groups. The opioid antagonists (-)naloxone and naltrexone potentiated the disruption of bar pressing induced by DMT and LSD. Failure of $(+)$-naloxone to potentiate the DMT effects was attributed to a stereospecific opioid antagonist effect of $(-)$-naloxone.
\end{abstract}

Key words: Opioid agonists - Antagonists - DMT - LSD Antagonism - Potentiation - FR 4 operant behavior

Historically, opioid agonists have been used in treatment of schizophrenia and other mental disorders, and numerous reports have demonstrated favorable, but inconsistent therapeutic effects in some psychotic patients (Woodward 1844, 1850; Carlson and Simpson 1963; Levinson 1971; Wellisch et al. 1971; Crow 1976; Comfort 1977a, b; Gold et al. 1977; Berken et al. 1978). However, further investigations of the therapeutic value of opioid agonists in mental disorders were overshadowed by the introduction of neuroleptic drug therapy (Delay and Deniker 1952), as well as the prevailing social and legal attitudes toward the use of opioids.

The purpose of this study was to further determine possible interactions of several opioid agonists and antagonists with DMT and LSD using a simple rodent model in which the behavioral effects of hallucinogens are well documented. Fertziger and Fischer (1977) reported that naloxone pretreatment in the rat shortened the LSD-induced excitatory

Offprint requests to: Secretary, Div. of Pharmacology, Lafayette Clinic, 951 East Lafayette, Detroit, MI 48207, USA phase and prolonged the cataleptic phase. In a previous investigation we reported that naloxone pretreatment potentiated DMT- and LSD-induced suppression of foodrewarded FR 4 behavior in the rat (Ruffing et al. 1979). The present report extends these findings to selected relatively pure opioid agonists and antagonists.

\section{Materials and Methods}

Male Holtzman rats at least 90 days old were maintained at approximately $70 \%$ of their expected free-feeding weight and housed separately in a constant temperature and humiditycontrolled facility.

Procedures. To establish food-rewarded bar pressing, rats were trained to press a bar daily for $1 \mathrm{~h}$ to receive $0.01 \mathrm{ml}$ reward of a sugared, evaporated milk solution as positive reinforcement. The milk solution was prepared by combining $400 \mathrm{ml}$ evaporated milk with $400 \mathrm{ml}$ tap water and $60 \mathrm{~g}$ granulated sugar. The daily bar pressing schedule was fixed ratio $4\left(\mathrm{FR}_{4}\right)$, i.e., a reward was earned on every fourth bar press. Experiments were conducted in a darkened, isolated room using Lehigh Valley Electronics rodent operant test cages (model 143-21). Operant behavioral data was collected automatically by Gerbrand cumulative recorders, illustrating bar pressing rates, reinforcements, and any disruption of normal bar pressing behavior during daily sessions. After achieving stable $\mathrm{FR}_{4}$ behavior, each rat was assigned daily 60-min bar pressing sessions for at least 5 days prior to injection. Procedures for training and experiment are similar to those described by Kovacic et al. (1978). Animals were drug-free for a minimum of 10 days prior to the experiment and had no past drug history, except for prior DMT and LSD administration. Rats were scheduled in randomly assigned groups $(N=5-11)$, while each rat served as its own control to compare the effects of a hallucinogen with and without the assigned pretreatment drug. Minimum 7-day drug-free intervals were observed between scheduled injections and control groups were pretreated with $0.9 \% \mathrm{NaCl}$ IP prior to the assigned hallucinogen injection. Doses of DMT (3.2 and $10.0 \mathrm{mg} / \mathrm{kg})$ and LSD $(0.1 \mathrm{mg} / \mathrm{kg})$ were administered IP to disrupt food-rewarded FR4 bar pressing behavior. The pretreatment drugs and doses used in this study were morphine sulfate and methadone $\mathrm{HCl}(0.32,1.0$, and $3.2 \mathrm{mg} / \mathrm{kg}$, (+)-naloxone $\mathrm{HCl}(3.2 \mathrm{mg} / \mathrm{kg}),(-)$-naloxone $\mathrm{HCl}$ $(1.0$ and $3.2 \mathrm{mg} / \mathrm{kg})$, and naltrexone $\mathrm{HCl}(1.16$ and $3.7 \mathrm{mg} / \mathrm{kg}$ ). Due to a limited supply of (+)-naloxone, a single pretreatment dose was used. The pretreatment drug doses described demonstrated no effect on normal bar pressing 
behavior for 120 -min periods, as predetermined in pilot studies. Doses of naltrexone were calculated in equimolar concentrations to naloxone. All dose levels refer to free base and all drugs were administered IP.

In the control pretreatment procedures, rats were injected IP with $0.9 \% \mathrm{NaCl}$, immediately placed in an operant chamber for $10-15$ min of bar pressing, injected IP with the assigned hallucinogen, and returned immediately to the operant chamber until the rat recovered and pressed the bar steadily at the preinjection control rate for a minimum $60-\mathrm{min}$ period. Animals were observed and behavioral responses were recorded for the duration of the drug effects and 60-min bar pressing session.

The drug pretreatment procedures were identical to the previously described control pretreatment procedures, but substituting assigned drugs for pretreatment injections. Behaviorally noneffective doses for pretreatment drugs used in this study were predetermined in pilot studies, whereby rats $(N=4)$ were placed in the operant chamber for $15 \mathrm{~min}$ of bar pressing, injected IP with the selected pretreatment dose, immediately returned to the operant chamber for a 120 -min bar pressing session (noneffective doses), or until the rat recovered (threshold disruptive dose) and bar pressed steadily at the preinjection control rate for a minimum $90-\mathrm{min}$ period.

Data Analysis. The significance of drug effects was determined from the length of the horizontal line generated by the cumulative recorder, illustrating the disruption of bar pressing behavior and duration of drug-induced effects. Twotailed Student's $t$-test paired comparison determinations were calculated according to Snedecor (1956), using the value of $P<0.05$ as significant.

Drugs. DMT was obtained from Sigma, St. Louis, Missouri, and solutions were prepared by dissolving the free base in $1 \mathrm{~N}$ $\mathrm{HCl}$, adding $0.9 \% \mathrm{NaCl}$, and adjusting the acidity with $0.1 \mathrm{NaOH}$ to render a $4.5-5.0 \mathrm{pH}$ for the final volume. LSD25 (Delysid) was obtained from the National Institute on Drug Abuse and was administered in $0.9 \% \mathrm{NaCl}$. Morphine sulfate was obtained from Pierce (Rockford, IL, 61105) and methadone $\mathrm{HCl}$ from Eli Lilly (Indianapolis, IN, 46285) and were administered in $0.9 \% \mathrm{NaCl}$. (-)-Naloxone $\mathrm{HCl}$ was generously supplied courtesy of the Endo Laboratories (Garden City, NY, 11530) and doses were administered in $0.9 \% \mathrm{NaCl}$. (+)-Naloxone $\mathrm{HCl}$ (NIH 9548) was supplied courtesy of Dr. Arthur E. Jacobson from the National Institute of Health, and was prepared by dissolving the compound in a solution of $0.9 \% \mathrm{NaCl}$ and $0.1 \mathrm{~N} \mathrm{HCl}$, adding $0.1 \mathrm{~N} \mathrm{NaOH}$ to adjust the acidity of the final volume, rendering a $4.3 \mathrm{pH}$. Naltrexone $\mathrm{HCl}$ was obtained from Endo (Labs.) and was administered in $0.9 \% \mathrm{NaCl}$.

\section{Results}

Cumulative bar pressing records of rats trained on foodrewarded FR 4 schedules typically show constant high response rates with only a very short post-reinforcement pause, followed by the same high response rates (Ferster and Skinner 1957; Thompson and Schuster 1968). Representative examples of cumulative FR 4 bar pressing records detailing response rates, and the abrupt onset, duration, and termination of effects induced by DMT $(3.2-10.0 \mathrm{mg} / \mathrm{kg})$ and LSD $(0.1 \mathrm{mg} / \mathrm{kg}$ ) have been previously reported (Kovacic and Domino 1976; Kovacic et al. 1978). Characteristic gross behavioral DMT- and LSD-induced effects were seen within

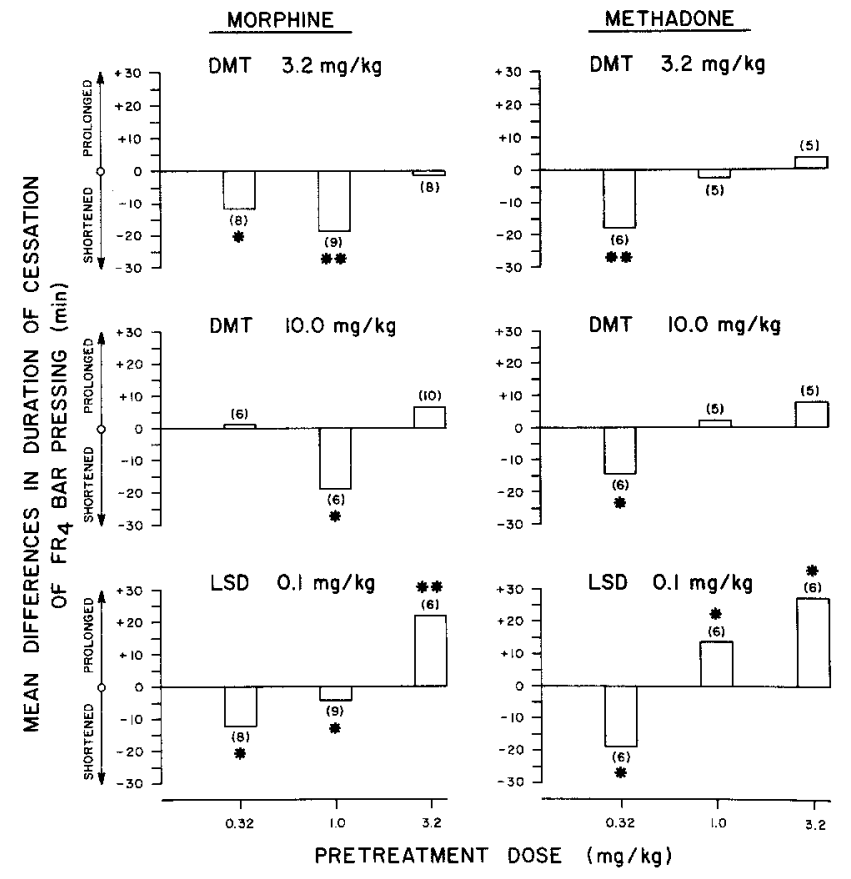

Fig. 1. Mean differences in the dose effect of morphine (left $)$ and methadone (right) pretreatment on the duration of DMT- and LSDinduced suppression of FR 4 bar pressing behavior in the rat. Groups $(N=5-10)$ received fixed doses of 3.2 or $10.0 \mathrm{mg} / \mathrm{kg} \mathrm{DMT}$ or $0.1 \mathrm{mg} / \mathrm{kg}$ LSD for control and pretreatment injections with each rat serving as its own control. Control treatment was $\mathrm{NaCl} 0.9 \% 10-15$ min prior to DMT or LSD. Predetermined behaviorally noneffective pretreatment doses were administered $10-15 \mathrm{~min}$ prior to DMT or LSD. Morphine $(0.32-1.0 \mathrm{mg} / \mathrm{kg})$ and methadone $(0.32 \mathrm{mg} / \mathrm{kg})$ pretreatment doses are shown to antagonize the effects of DMT- and LSD-induced disruption of FR 4 behavior, whereas morphine $(3.2 \mathrm{mg} / \mathrm{kg})$ and methadone $(1.0-$ $3.2 \mathrm{mg} / \mathrm{kg}$ ) potentiated LSD-induced effects, showing no significant effect differences in DMT groups. In this and subsequent figures, pairedcomparison Student's $t$-tests were used $\left({ }^{*} P<0.05,{ }^{* *} P<0.01\right.$, $* * * P<0.001)$. Also, all injections were administered IP and numerals in parentheses represent the number of animals in designated groups

$2-5$ min following IP injections. These consisted of prolonged periods of lying quietly in an excessively flattened position with eyes open, crawling in a flattened position, jerky movements, arching, occasional repetitious head and/or body movements, cage circling, muscular twitching, flattening and extension of the hind limbs, occasional Straub tail, walking backwards, and disinterest in food and/or bar pressing. The observed gross behavioral DMT- and LSD-induced effects were consistent in all treatment groups, except morphine and methadone. Morphine-pretreated rats displayed fewer, and markedly reduced gross behavioral effects (i.e., brief periods of lying and sitting quietly with minimal flattening, periodic interest in food and/or bar pressing, and reduced muscular twitching and movement jerkiness). Intensified gross behavioral effects were observed in the methadone-pretreated groups (i.e., markedly increased display of flattening, repetitious head and body movements, Straub tail, and muscular twitching). At the cessation of drug effects all rats would groom briefly, then abruptly start and continue bar pressing at preinjection control rates.

Figure 1 illustrates biphasic dose effects (expressed as mean differences in minutes) of the opiate agonists, morphine (left), and methadone (right) at $0.32,1.0$, and $3.2 \mathrm{mg} / \mathrm{kg}$ IP 
Table 1. Mean duration of DMT- and LSD-induced disruption of food-rewarded FR 4 bar pressing in control (0.9\% NaCl-pretreated) and corresponding opioid agonist- or antagonist-pretreated rats. All pretreatments were at $10-15$-min intervals

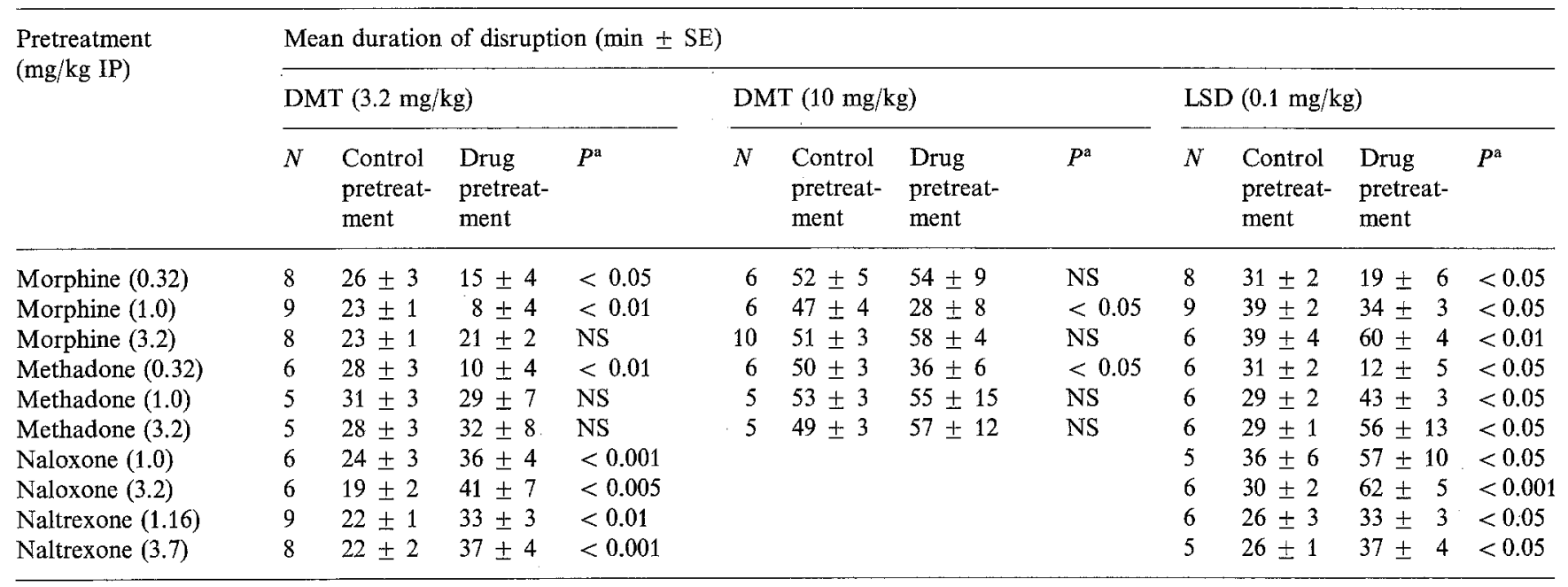

a Paired-comparison $t$-tests

pretreatment $10-15 \mathrm{~min}$ prior to IP DMT $(3.2$ and $10.0 \mathrm{mg} / \mathrm{kg})$ and $\operatorname{LSD}(0.1 \mathrm{mg} / \mathrm{kg})$. While significant antagonism of the DMT- and LSD-induced behavioral suppressant effects is shown with doses of $0.32-1.0 \mathrm{mg} / \mathrm{kg}$ IP morphine and $0.32 \mathrm{mg} / \mathrm{kg}$ IP methadone, $3.2 \mathrm{mg} / \mathrm{kg}$ IP morphine and $1.0-3.2 \mathrm{mg} / \mathrm{kg}$ IP methadone potentiated the LSD-induced effects, but not the DMT effects. Table 1 shows the duration of DMT- and LSD-induced disruption of FR4 bar pressing (mean $\pm \mathrm{SE})$ for the control $(0.9 \% \mathrm{NaCl}$ pretreated group) and corresponding morphine- or methadone-pretreated groups.

In contrast, pretreatment $(10-15 \mathrm{~min})$ with the opioid antagonists naloxone $(1.0-3.2 \mathrm{mg} / \mathrm{kg} \mathrm{IP})$ and equimolar naltrexone doses $(1.16-3.7 \mathrm{mg} / \mathrm{kg} \mathrm{IP})$ significantly potentiated effects of DMT $(3.2 \mathrm{mg} / \mathrm{kg})$ and LSD $(0.1 \mathrm{mg} / \mathrm{kg})$ on behavior, as expressed in mean differences (Fig. 2). Mean $( \pm \mathrm{SE})$ durations of disruption of bar pressing for the control $(0.9 \% \mathrm{NaCl}$-pretreated group) and corresponding naloxoneor naltrexone-pretreated group are also shown in Table 1.

Stereospecific effects of $3.2 \mathrm{mg} / \mathrm{kg}$ IP $(+)$-naloxone and $3.2 \mathrm{mg} / \mathrm{kg}$ IP ( $\rightarrow$ )-naloxone (commonly referred to as naloxone) pretreatment $10-15 \mathrm{~min}$ prior to DMT $(3.2 \mathrm{mg} / \mathrm{kg}$ IP) are shown in Fig. 3. No significant DMT-effect differences were observed in the $(+)$-naloxone-pretreated group is contrast to the potentiation of DMT-induced effects observed with the ( - -)-naloxone enantiomer pretreatment. Mean ( $\pm S E)$ durations of cessation of bar pressing for controls and corresponding $(+)$-and $(-)$-naloxone-pretreated groups were : $0.9 \%: \mathrm{NaCl}-\mathrm{DMT} 3.2 \mathrm{mg} / \mathrm{kg}, 24 \pm 2$, and (+)-naloxone 3.2-DMT $3.2 \mathrm{mg} / \mathrm{kg}, 15 \pm 6 ; 0.9 \% \mathrm{NaCl}-\mathrm{DMT} 3.2 \mathrm{mg} / \mathrm{kg}$, $19 \pm 2$, and (-)-naloxone 3.2-DMT $3.2 \mathrm{mg} / \mathrm{kg}, 41 \pm 7$, respectively.

\section{Discussion}

The results of the present study extend previous observations that naloxone potentiated DMT-and LSD-induced disruption of food-rewarded bar pressing in the rat (Ruffing et al. 1979), as well as recent findings that naloxone additionally potentiated the disruptive effects of mescaline (Commissaris et al. 1980). It is generally known that the biologically active

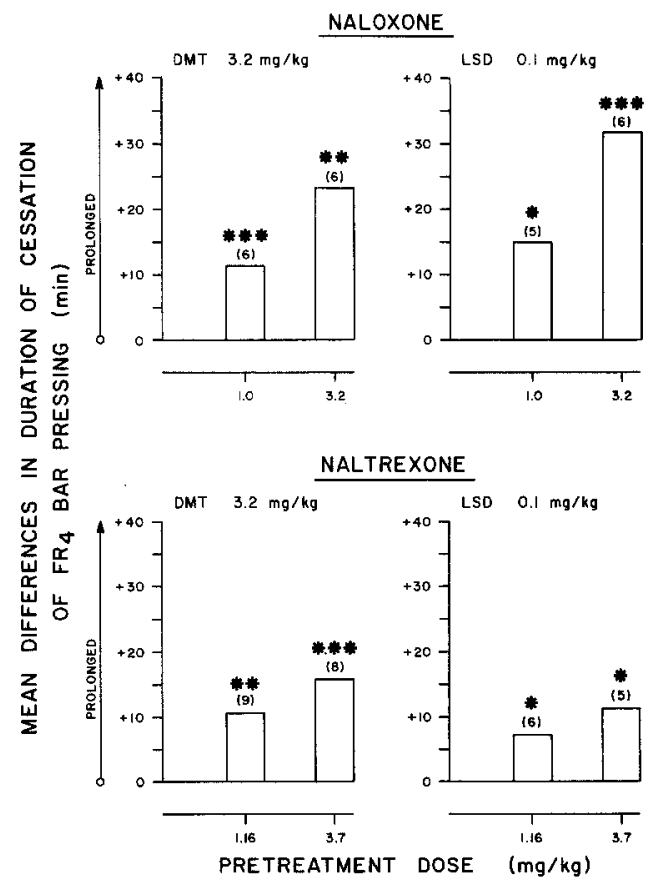

Fig. 2. Comparison of the potentiating effects of naloxone (top) and naltrexone (bottom) pretreatment on the duration of DMT- and LSDinduced suppression of FR 4 bar pressing behavior in the rat. Groups $(N=5-9)$ received a fixed dose of DMT $(3.2 \mathrm{mg} / \mathrm{kg})$ or LSD $(0.1 \mathrm{mg} / \mathrm{kg})$ for control and pretreatment injections with each rat serving as its own control. Graph points represent the mean differences in bar pressing disruption time $(\mathrm{min})$ for the control and corresponding pretreatment group. Control treatment was $0.9 \% \mathrm{NaCl} 10-15$ min prior to DMT or LSD. Predetermined behaviorally noneffective pretreatment doses of naloxone $(1.0-3.2 \mathrm{mg} / \mathrm{kg})$ and equimolar naltrexone doses $(1.16-3.7 \mathrm{mg} / \mathrm{kg})$ were administered $10-15 \mathrm{~min}$ prior to DMT or LSD. $* P<0.05,{ }^{* *} P<0.01,{ }^{* * *} P<0.001$

narcotic antagonist is the (-)-naloxone isomer (Pert and Snyder 1973; Gayton et al. 1978; Iijima et al. 1978; Jacquet 1980; Herz et al. 1979). Thus, it is of special interest that in the present study $(+)$-naloxone was inactive in potentiating the effects of DMT, confirming stereospecificity. 


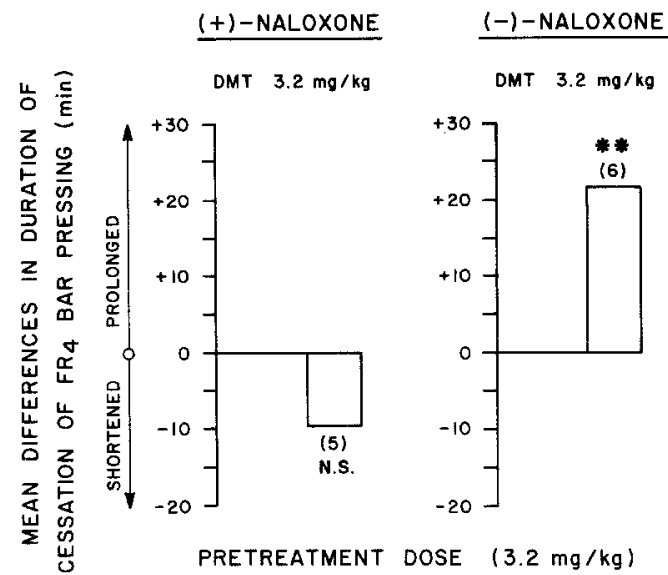

Fig. 3. Stereospecific dose effects of $(+)$ - and (-)-naloxone pretreatment on the duration of DMT-induced disruption of FR 4 bar pressing behavior in the rat. Groups of animals $(N=5-6)$ received a fixed dose of DMT $(3.2 \mathrm{mg} / \mathrm{kg}$ ) for control and pretreatment injections with each rat serving as its own control. Graph points represent the mean differences in bar pressing disruption time (min) for the control and corresponding pretreatment group. Control treatment was $0.9 \% \mathrm{NaCl} 10-15 \mathrm{~min}$ prior to DMT. The pretreatment drug dose $[3.2 \mathrm{mg} / \mathrm{kg}(+)$-naloxone], predetermined as behaviorally noneffective, was administered $10-15 \mathrm{~min}$ prior to DMT. Potentiation of DMT-induced effects is shown in the $(-)$-naloxone isomer pretreatment group (right), with no significant effect differences (NS) shown in the ( + )-naloxone isomer pretreatment group (left). ${ }^{* *} P<0.01$

Since pure narcotic antagonists, such as naloxone and naltrexone, potentiated the effects of DMT and LSD, one would expect narcotic agonists, such as morphine and methadone, to have opposite or antagonizing effects. This is indeed what occurred with small to moderate doses of both narcotic agonists, while larger doses of both narcotics did not antagonize the disruptive bar pressing effects of either DMT or LSD, but actually potentiated the LSD-induced effects. The data indicate a very important dose-effect relationship not only for the opioids, but also for the hallucinogens. For example, the larger DMT dose $(10.0 \mathrm{mg} / \mathrm{kg})$, when compared to $3.2 \mathrm{mg} / \mathrm{kg}$ DMT, was less effectively antagonized by both morphine and methadone. These dose-effect differences may be related to different modes of DMT clearance in the brain, with $10.0 \mathrm{mg} / \mathrm{kg}$ DMT having the slower rate of clearance, since tertiary amines can be weak MAO inhibitors and DMT inhibits this enzyme (Carlsson and Lindquist 1972; Lu and Domino 1976; Lu et al. 1974). Although DMT and LSD similarly depress serotonin-containing neurons (Jacobs et al. 1977), it is known that LSD additionally has dopamine (DA) agonist-antagonist activity (Meltzer et al. 1977; Pieri et al. 1974; Von Hungen et al. 1974; DaPrada et al. 1975). Harris et al. (1977) reported that naloxone potentiated the ratedecreasing effects of low doses of DA agonists like apomorphine and ET-495. While this might explain naloxone potentiation of LSD, it does not explain the potentiation of DMT.

LSD and morphine have been reported to antagonize certain actions of each other. LSD antagonizes morphineinduced analgesia in rats (Dhawan and Gupta 1959), emesis in dogs (Dhawan and Gupta 1961), and some narcotic actions of morphine (Murphree 1965). Conversely, morphine antagonizes LSD-induced pyrexia in rabbits (Dhawan 1960), and LSD-induced hypotension and carotid occlusion response in dogs (Gupta et al. 1968). A search for the morphine crystal pharmacophoric pattern coordinates in other mol- ecules, consisting of the aromatic ring and remote nitrogen atom, disclosed the identical crystal structure in LSD as an important molecular similarity (Gund 1977).

It should be noted that the severity of gross behavioral effects did not always correlate with the cessation of drug effects or onset of bar pressing. For example, methadone $(0.32 \mathrm{mg} / \mathrm{kg})$ plus DMT or LSD intensified severe gross behavior, but showed less suppression of bar pressing.

Currently, much literature exists that is highly controversial, regarding the role of endogenous opiates in mental disease, as to whether naloxone antagonizes hallucinations in schizophrenic patients, and whether $\beta$-endorphin is therapeutically beneficial (Usdin et al. 1979). The present study indicates important dose-effect relationships that must be taken into account before any sweeping generalizations can be made. A possibility for the seemingly contradictory findings in rats and humans suggest that both physiological and pharmacological interactions may be occurring. However, our unpublished results when using a nonopiate control drug such as chlorpromazine, demonstrate no antagonism of the effects of either DMT or LSD. These results indicate that small doses of opioids are selective antagonists of DMT and LSD, at least in the rat. Further studies are needed to determine specific peripheral and central effects of hallucinogens and opioid interactions. Especially important would be a study of $(+)$-morphine, a compound devoid of narcotic analgesic properties but said to retain some opioid behavioral effects (Jacquet et al. 1977). The present study indicates that there are important and generally consistent interactions between DMT, LSD, and opioids in the rat. The data reinforce a possible role of opioids in mental processes involving hallucinogenic substances.

Acknowledgements. A special thank you to Ms. Deborah Ashley for her patience in typing the manuscript and to Mr. Bill Reynolds for his expertise in drawing the figures.

\section{References}

Berken GH, Stone MM, Stone SK (1978) Methadone in schizophrenic rage: A case study. Am J Psychiatry 135:248-249

Carlson ET, Simpson MM (1963) Opium as a tranquilizer. Am J Psychiatry $120: 112-117$

Carlsson A, Lindquist M (1972) The effect of L-tryptophan and some psychotropic drugs on the formation of 5-hydroxytryptophan in the mouse brain in vivo. J Neural Trans 33:23-43

Comfort A (1977a) Morphine as antipsychotic drug. Lancet I:95

Comfort A (1977b) Morphine as an antipsychotic? Clin Toxicol $11: 383-386$

Commissaris RL, Moore KE, Rech RH (1980) Naloxone potentiates the disruptive effects of mescaline on operant responding in the rat. Pharmacol Biochem Behav 13:601-603

Crow TJ, Deakin JFW, Johnstone EC, Longden A (1976) Dopamine and schizophrenia. Lancet II, 1027

DaPrada M, Soner A, Burkard W, Batholini G, Pletscher A (1975) Lysergic acid diethylamide: Evidence for stimulation of central dopamine receptors. Brain Res 94:67-73

Delay J, Deniker P (1952) Trente-huit cas de psychoses traitees par la cure prolongec et continue de 4560 RP. Le Congres des Al. et Neurol. de Langue France. In: Compte rendu Congres, p 443, Masson, Paris

Dhawan BN (1960) Blockade of LSD-25 pyrexia by morphine. Arch Int Pharmacodyn Ther 127:307-313

Dhawan BN, Gupta GP (1959) LSD-25 antagonism of morphine analgesia. Arch Int Pharmacodyn Ther 123:132-139

Dhawan BN, Gupta GP (1961) Antiemetic activity of $d$-lysergic acid diethylamine. J Pharmacol Exp Ther 133:137-139

Ferster CB, Skinner BF (1957) Schedules of reinforcement. Appleton Century Crofts, New York 
Fertziger A, Fischer R (1977) Interaction between narcotic antagonist (naloxone) and lysergic acid diethylamide (LSD) in the rat. Psychopharmacology 54:313-314

Gayton RJ, Lambert LA, Bradley PB (1978) Failure of (+)-naloxone to antagonize responses to opioid peptides. Neuropharmacology $17: 549-551$

Gold MS, Donabedian RK, Dillard, M Jr, Slobetz FW, Riordan CE, Kleber HD (1977) Antipsychotic effect of opiate agonists. Lancet II, $398-399$

Gund P (1977) Three-dimensional pharmacophoric pattern searching. In: Hahn FE (ed) Progress in molecular and subcellular biology, Vol 5. Springer, Berlin Heidelberg New York, pp 117-143

Gupta GP, Dhawan KN, Dhawan BN (1968) Antagonism of central vasomotor effects of lysergic acid diethylamide (LSD-25) by morphine. Jpn J Pharmacol 18:255-259

Harris RA, Snell D, Loh HH, Way EL (1977) Behavioral interactions between naloxone and dopamine agonists. Eur J Pharmacol $43: 243-246$

Herz A, Blasig J, Fry JP, Hollt V, Meyer G, Prezewlocki R (1979) Opiate receptors, their endogenous ligands and the development of tolerance/dependence. In: Jacob J (ed) Advances in pharmacology and therapy, Vol 1. Receptors. Pergamon Press, New York, pp $47-$ 57

Iijima I, Minamikawa J, Jacobson AE, Brossi A, Rice KC (1978) Studies in the $(+)$-morphinan series. 5. Synthesis and biological properties of (+)-naloxone. J Med Chem 21:398-400

Jacobs BL, Trulson ME, Stern WC (1977) Behavioral effects of LSD in the cat: Proposal of an animal behavior model for studying the actions of hallucinogenic drugs. Brain Res 132:301-314

Jacquet YF (1980) Stereospecific, dose-dependent antagonism by naloxone of nonopiate behavior in mice. Pharmacol Biochem Behav $13: 585-587$

Jacquet YF, Klee WA, Rice KC, Iijima I, Minawikawa J (1977) Stereospecific and nonstereospecific effects of $(+)$ - and $(-)$-morphine. Evidence for a new class of receptors. Science 198:842-845

Kovacic B, Domino EF (1976) Tolerance and limited cross-tolerance to the effects of N,N-dimethyltryptamine (DMT) and lysergic acid diethylamide-25 (LSD) on food-rewarded bar pressing in the rat. J Pharmacol Exp Ther 197:495-502

Kovacic B, Lu LJ Wang, Ruffing D, Domino EF (1978) Interactions of partial LSD analogs with behavioral disrupting effects of LSD and DMT in the rat. Eur J Pharmacol 47:37-44
Levinson P (1971) Addiction induction: Will it be tested? Perspect Biol Med 14:671-674

Lu LJ, Domino EF (1976) Effects of iproniazid and tranylcypramine on the half-life of $\mathrm{N}, \mathrm{N}$-dimethyltryptamine in rat brain and liver. Biochem Pharmacol 23:1521-1527

Lu LJ, Wilson AE, Moore RH, Domino EF (1974) Correlation between brain N,N-dimethyltryptamine (DMT) levels and bar pressing behavior in rats: Effect of MAO inhibition. Pharmacologist $16: 237$

Meltzer HY, Fessler RG, Simonovic M, Doherty J, Fang VS (1977) Lysergic acid diethylamide: Evidence for stimulation of pituitary dopamine receptors. Psychopharmacology 54:39-44

Murphree HB (1965) Narcotic analgesics. I. Opium alkaloids. In: Dipalma JR (ed) Drill's pharmacology in medicine. McGraw Hill, New York, pp 252-265

Pert CB, Snyder SH (1973) Opiate receptor: Demonstration in nervous tissue. Science 179:1011-1015

Pieri L, Pieri M, Haefely W (1974) LSD as an agonist of dopamine receptors in the striatum. Nature 252:586-588

Ruffing D, Kovacic B, Demetriou S, Domino EF (1979) Naloxone enhancement of DMT- and LSD-25-induced suppression of foodrewarded bar pressing behavior in the rat. Psychopharmacology $62: 207-210$

Snedecor GW (1956) Statistical methods. Iowa State College Press, Ames

Thompson T, Schuster CR (1968) The classification of behavior. In Behavioral pharmacology. Prentice Hall, Englewood Cliffs, pp 98136

Usdin E, Bunney WE, Kline NS, eds (1979) Endorphins in mental health research. London, MacMillan

Von Hungen K, Roberts S, Hill DF (1974) LSD as an agonist and antagonist at central dopamine receptors. Nature 252:588-589

Wellisch DK, Gay GG, Wesson DR, Smith DE (1971) The psychotic heroin addict. J Psychedelic Drugs 4:46-49

Woodward SB (1844) Twelfth Annual Report of the State Lunatic Hospital at Worcester, December 1844. Dutton and Wentworth, Boston

Woodward SB (1850) Observations of medical treatment on insanity. Am J Insane $7: 1$

Received December 22, 1980; Final version June 22, 1981 